\title{
Influence of Integrated Use of Organic Manures and Inorganic Sources of Nitrogen on Grain Yield and its Attributes in Rice (Oryza sativa L.)
}

\author{
C. Sudhakar ${ }^{1 *}$, P. Padmavathi ${ }^{2}$, B.V. Asewar ${ }^{3}$, P. Venkateswar Rao and A. Sai Ram ${ }^{5}$ \\ ${ }^{1}$ Agronomy, Agricultural Research Station, Tandur-501141, Telangana \\ Prof. Jayashankar Telangana State Agricultural University, India \\ ${ }^{2}$ Agronomy, Indian Institute of Oilseeds Research, Hyderabad-500030, Telangana, India \\ ${ }^{3}$ Agronomy, All India Coordinated Research Project on Dryland Agriculture, VNMKV, \\ Parbhani-431402, Maharashtra, India \\ ${ }^{4}$ Department of Plant Physiology, College of Agriculture, Rajendranagar, Hyderabad- \\ 500030, Telangana, PJTSAU, India \\ ${ }^{5}$ Soil Science \& Agril. Chemistry, Radio Tracer Laboratory, Agricultural Research Institute, \\ Rajendranagar, Hyderabad-500030 Telangana, PJTSAU, India
}

*Corresponding author

\section{Key words}

Rice, INM, Organic

Manures, Inorganic

Fertilizers and yield

Article Info

Accepted:

25 October 2018

Available Online:

10 November 2018

\section{A B S T R A C T}

An investigation was carried out to study the influence of pre-rice incorporation of organic manures viz., green manure and farm yard manure (FYM) and simultaneously, the effect of inorganic source of Nitrogen at different levels was also studied to assess the influence of graded Nitrogen levels on productivity of rice. The results indicated that the organic manurial options i.e., in-situ incorporation of green manure crop (Sesbania aculeata) and farm yard manure @ $10 \mathrm{t}$. ha ${ }^{-1}\left(\mathrm{M}_{2}\right.$ and $\mathrm{M}_{3}$, respectively) significantly influenced the plant growth of rice in terms of plant height, dry matter production, leaf area index etc., in comparison to no manuring treatment $\left(\mathrm{M}_{1}\right)$. Similarly, the yield attributes and grain yield were also significantly enhanced due to both the organic manurial options. Among organic treatments, in-situ incorporation of green manure (Sesbania aculeata) proved its superiority in increasing grain and straw yields of rice over farm yard manure @ $10 \mathrm{t}$. ha ${ }^{-1}$ in the first year only (4479 and $5211 \mathrm{~kg} \mathrm{ha}^{-1}$, respectively). The advantage due to $\mathrm{M}_{2}$ and $\mathrm{M}_{3}$ in increasing the grain yield was by 17.4 and $10.4 \%$ in the first year and; 19.2 and $21.1 \%$ in the second year, respectively over no manuring treatment. As regards to the influence of Nitrogen levels, increasing the levels from 0 to $150 \%$ RDN brought significant improvement in plant growth, development, yield attributes and yield of kharif rice during both years of study. Application of $150 \%$ RDN increased the grain yields to an extent of $11.8 \%$ in the first year and $8.7 \%$ in the second year over $100 \%$ RDN.

\section{Introduction}

Rice (Oryza sativa $\mathrm{L}$.) is the most important staple food crop for more than 60 per cent of the global population. In India, rice is cultivated in an area of $43.49 \mathrm{~m}$ ha with an annual production of $104.40 \mathrm{~m} \mathrm{t}$ and average productivity of $2400 \mathrm{~kg} \mathrm{ha}^{-1}$. In Telangana, it 
covers an area of $1.04 \mathrm{~m}$ ha with a production of $3.04 \mathrm{~m} \mathrm{t}$ tonnes and average productivity of $2913 \mathrm{~kg} \mathrm{ha}^{-1}$ (Indiastat, 2015-16). In India the escalating demographic pressure, food demand of the country combined with dwindling productivity levels of food crops are forcing the farmers of rice based agroecosystem to adopt more intensive farming systems. On the other hand, the present chemical based agricultural production systems are contributing towards the environmental pollution and soils degradation and thus destabilizing the natural resource base in Indian agriculture in general and in rice based agro-ecosystems in particular. Food and Agriculture Organization (FAO) conceptualized the idea of plant nutrition based on cropping system as a whole rather than a single crop in the system and enhancing of soil fertility through better soil management systems (Roy and Braun, 1984. The fertilizer need of a crop in a system is strongly influenced by the preceding crops and the amount of fertilizers applied to them. Cereals like rice demand sound and effective nutrient management for achieving productivity targets and soil fertility sustainability. Among the major nutrients, nitrogen is pivotal in yield realization of rice. INM systems seek to maintain or improve soil fertility for sustaining the desired levels of crop production and productivity through optimization of benefits from all possible sources of plant nutrients in an integrated manner (Kundu and Pillai, 1992). It entails the conjunctive use of compost FYM, vermicompost, crop residues, green manures, crop rotation, biofertilizers and chemical fertilizers in a compatible manner. Growing and in-situ incorporation of green manures (Sesbania aculeata) during summer with premonsoon showers result in a significant contribution to soil nutrient status by augmenting nitrogen and economics by reducing energy inputs (Bajpai et al., 2004). Further, an integrated supply of FYM with chemical fertilizers in kharif rice minimized use of chemical fertilizers to a greater extent without affecting the rice yield and conserved the soil fertility status for succeeding crop. Nutrient recommendations for crops is usually made based on the responses of individual crops in the system without considering the total requirement of crops grown in cropping system as a whole and nutrient interactions between them. As a result, the recommendations often proved to be nonremunerative. Therefore, for efficient nutrient management in rice based cropping systems, a quantitative evaluation of the role of preceding crop and the residual effect of nutrients applied assumes great importance.

\section{Materials and Methods}

The present investigation was conducted during two consecutive years (i. e. 2008-09 and 2009-10) at College Farm, College of Agriculture, Rajendranagar, Hyderabad to study the effect of continued use of organic and inorganic sources of nitrogen on the sustainable crop productivity in rice. The farm is geographically situated at an altitude of $542.6 \mathrm{~m}$ above mean sea level on $17^{\circ} 19^{\prime} \mathrm{N}$ latitude and $78^{\circ} 23^{\prime} \mathrm{E}$ longitude. It is covered under Southern Telangana Agro-climatic zone of Telangana State. According to Troll's climatic classification, it falls under semi-arid tropic region (SAT).The experiment was laid out in a split plot design comprising of three main plot treatments (organic manural options viz., no manuring, in-situ incorporation of green manure crop (Sesbania aculeata) and farm yard manure @ 10 t. ha ${ }^{-1}$ i.e., $\mathrm{M}_{1}, \mathrm{M}_{2}$ and $\mathrm{M}_{3}$, respectively) and seven sub-plot treatments(four levels of Nitrogen viz., 0, 50, 100 and $150 \%$ RDN $\left(\mathrm{N}_{1}, \mathrm{~N}_{2}, \mathrm{~N}_{3}\right.$ and $\left.\mathrm{N}_{4}\right)$ and also three more levels of Nitrogen i.e., 50, 100 and $150 \%$ RDN $\left(\mathrm{N}_{5}, \mathrm{~N}_{6}\right.$ and $\left.\mathrm{N}_{7}\right)$, replicated thrice. The experimental data was recorded on plant growth and development (Plant height (cm), Leaf Area Index (LAI), Dry matter 
production $(\mathrm{kg} / \mathrm{ha})$, Number of tillers $/ \mathrm{m}^{2}$, Days to 50 per cent flowering, Days to physiological maturity, Chlorophyll Content (SPAD values), Per cent solar radiation interception by the crop canopy), yield attributes and yield of rice during both the years of study (Panicle length $(\mathrm{cm})$, Number of spikelet's per panicle, Filled spikelet's per panicle, Per cent spikelet sterility, Test weight $(\mathrm{g})$, Grain yield $\left(\mathrm{kg} \mathrm{ha}^{-1}\right)$, Straw yield $\left(\mathrm{kg} \mathrm{ha}^{-1}\right)$ and Harvest index (\%)).

\section{Treatment details}

Main plot treatments: (Organic manuring options)

M1 - No Manuring

M2 - in-situ Incorporation of green manure crop (Sesbania aculeata)

M3-Farm yard manure@ 10 t. ha ${ }^{-1}$

Sub-plot treatments: (Nitrogen levels)

\begin{tabular}{|l|c|l|l|}
\hline \multicolumn{2}{|c|}{ Rice (Kharif) } & \multicolumn{2}{c|}{ Rice (Kharif) } \\
\hline $\mathrm{N}_{1}$ & $\begin{array}{c}\text { Control (No } \\
\text { nitrogen) }\end{array}$ & $\mathrm{N}_{5}$ & $\begin{array}{l}50 \% \mathrm{RDN}(60 \\
\left.\mathrm{N} \mathrm{kg} \mathrm{ha}^{-1}\right)\end{array}$ \\
\hline $\mathrm{N}_{2}$ & $\begin{array}{c}50 \% \mathrm{RDN}^{-1}(60 \\
\left.\mathrm{N} \mathrm{kg} \mathrm{ha}^{-1}\right)\end{array}$ & $\mathrm{N}_{6}$ & $\begin{array}{l}100 \% \mathrm{RDN} \\
\left(120 \mathrm{Ng} \mathrm{ha}^{-1}\right)\end{array}$ \\
\hline $\mathrm{N}_{3}$ & $\begin{array}{c}100 \% \mathrm{RDN}^{-1} \\
\left(120 \mathrm{Ng} \mathrm{ha}^{-1}\right)\end{array}$ & $\mathrm{N}_{7}$ & $\begin{array}{l}150 \% \mathrm{RDN} \\
\left(180 \mathrm{Ng} \mathrm{ha}^{-1}\right)\end{array}$ \\
\hline $\mathrm{N}_{4}$ & $\begin{array}{c}150 \% \mathrm{RDN}^{-1} \\
\left(180 \mathrm{Ng} \mathrm{ha}^{-1}\right)\end{array}$ & & \\
\hline
\end{tabular}

Note:

To have better interpretation of the kharif rice results, the duplicated treatments viz., N2 and N5 (50\% RDN); N3 and N6 (100\% RDN): and N4 and N7 (150\% RDN) were averaged and represented as $\mathrm{N} 2, \mathrm{~N} 3$ and N4.The mean values are subjected to statistical analysis

\section{Statistical analysis}

The data recorded on various parameters were analyzed following the analysis of variance for split-plot design as suggested by Gomez and Gomez (1984). Wherever, the treatment differences were found significant (F-test), critical differences were worked out at five per cent probability level and furnished along with mean values of the parameter concerned in tables. Treatment differences that were nonsignificant were denoted by 'NS'.

\section{Results and Discussion}

Organic manuring practices and nitrogen levels have significantly influenced the growth parameters of rice viz., plant height, number of tillers, leaf area index and dry matter production at various crop growth stages during both the years of study. The results pertaining to various biometric observations were presented in Table 1. Among organic manuring treatments, green manuring with Sesbania or FYM @ $10 \mathrm{t} \mathrm{ha}^{-1}$ produced significantly taller rice plants with maximum leaf area index, higher tiller numberand more dry matter production at all the stages of crop growth in both the years as compared to no organic manuring treatment. Nitrogen application at $150 \%$ RDN resulted in significantly taller rice plants with higher leaf area index, maximum tiller number and highest dry matter.Similar reports of improvement in growth characters due to higher $\mathrm{N}$ levels have been reported by Sunitha, (2003) and Pramanik et al., (2004). The significant increase in leaf area index (LAI) with increased levels of nitrogenwas earlier reported by Muhammad Usman et al., 2003). Similarly, BalajiNaik and Yakadri (2004) also reported that with each successive increment of $\mathrm{N}$ by $50 \mathrm{~kg} \mathrm{ha}^{-1}$ upto $150 \mathrm{~kg} \mathrm{ha}^{-1}$, the dry matter accumulation increased significantly.However, the growth structure with $50 \% \mathrm{RDN}+$ green manuring or FYM application was comparable with sole application of $100 \%$ or $150 \%$ RDN in inorganic form. Conjunctive use of $50 \%$ of RDN along with green manuring $\left(\mathrm{M}_{2} \mathrm{~N}_{2}\right)$ or FYM @ $10 \mathrm{t} \mathrm{ha}^{-1}\left(\mathrm{M}_{3} \mathrm{~S}_{2}\right)$ resulted in statistically on par number of tillers per $\mathrm{m}^{2}$ and dry matter production with that of 100 
and $150 \% \mathrm{RDN}$ in no manured treatment $\left(\mathrm{M}_{1}\right.$ $\mathrm{N}_{3}$ and $\mathrm{M}_{1} \mathrm{~N}_{4}$, respectively).. Similar findings were reported by Mari et al., (2004). Leaf chlorophyll content (SPAD values) and per cent solar radiation interception (Table 3 and Fig 1)were also significantly higher with Sesbania green manure or FYM @ $10 \mathrm{t}$ ha
${ }^{1}$ along with the application of nitrogen @ $150 \% \mathrm{RDN}$ in both the years. Integration of green manure $+50 \%$ RDN stood at par with $100 \%$ RDN without organic manuring. The results obtained in this study are in line with the findings of Chandrapala, (2009).

Table.1 Various growth parameters of rice at harvest as influenced by organic manuring options and nitrogen levels

\begin{tabular}{|c|c|c|c|c|c|c|c|c|}
\hline \multirow{2}{*}{$\begin{array}{l}\text { Treatments } \\
\text { Organic manuring options (M) }\end{array}$} & \multicolumn{2}{|c|}{$\begin{array}{l}\text { Plant height } \\
\text { (cm) }\end{array}$} & \multicolumn{2}{|c|}{$\begin{array}{l}\text { Number of } \\
\text { tillers of rice } \\
\text { per } \mathrm{m}^{2}\end{array}$} & \multicolumn{2}{|c|}{$\begin{array}{l}\text { Leaf Area } \\
\text { Index (LAI) } \\
\text { at90 DAT }\end{array}$} & \multicolumn{2}{|c|}{$\begin{array}{l}\text { Dry matter } \\
\text { production of } \\
\text { rice }\left(\mathrm{kg} \mathrm{ha}^{-1}\right)\end{array}$} \\
\hline & 2008 & 2009 & 2008 & 2009 & 2008 & 2009 & 2008 & 2009 \\
\hline$M_{1}$ - No manuring & 95.7 & 98.1 & 284. & 299.1 & 4.93 & 5.04 & 8051 & 8428 \\
\hline $\mathrm{M}_{2}$ - In-situ incorporation of $S$. & 105. & 109. & 343. & 370.1 & 5.06 & 5.27 & 9691 & 10407 \\
\hline $\mathrm{M}_{3}$ - Farm yard manure @ $10 \mathrm{t} \mathrm{ha}^{-1}$ & 103. & 103. & 316. & 379.3 & 5.01 & 5.11 & 8930 & 10680 \\
\hline $\mathrm{SEm} \pm$ & 1.58 & 2.17 & 1.43 & 7.24 & 0.00 & 0.00 & 36.5 & 208.3 \\
\hline C.D. $(P=0.05)$ & 6.20 & 8.52 & 5.61 & 28.40 & 0.01 & 0.01 & 143. & 817.9 \\
\hline \multicolumn{9}{|l|}{ Nitrogen levels (N) } \\
\hline $\mathbf{N}_{1}$ - Control (No nitrogen) & 95.1 & 93.9 & 247 & 226.5 & 4.63 & 4.76 & 6980 & 6414 \\
\hline $\mathrm{N}_{2-}-50 \%$ RDN $\left(60 \mathrm{~kg} \mathrm{ha}^{-1}\right)$ & 98.4 & 97.9 & 295 & 335.7 & 4.76 & 4.88 & 8328 & 9434 \\
\hline $\mathrm{N}_{3^{-}}-100 \%$ RDN $\left(120 \mathrm{~kg} \mathrm{ha}^{-1}\right)$ & 102. & 108.8 & 336 & 398.9 & 5.08 & 5.23 & 9400 & 11139 \\
\hline $\mathrm{N}_{4-}-150 \%$ RDN $\left(180 \mathrm{~kg} \mathrm{ha}^{-1}\right)$ & 110. & 113.4 & 380 & 436.8 & 5.54 & 5.67 & 1085 & 12365 \\
\hline SEm \pm & 1.21 & 1.61 & 1.7 & 8.67 & 0.00 & 0.01 & 49.6 & 242.9 \\
\hline C.D $(\mathbf{P}=\mathbf{0 . 0 5})$ & 3.59 & 4.79 & 5.2 & 25.75 & 0.03 & 0.05 & 147. & 721.7 \\
\hline \multicolumn{9}{|l|}{ Interaction (M X N) } \\
\hline \multicolumn{9}{|l|}{ Between two $\mathrm{N}$ at the same $\mathrm{M}$} \\
\hline $\mathrm{SEm} \pm$ & 2.09 & 2.80 & 3.0 & 15.00 & 0.02 & 0.03 & 85.9 & 420.7 \\
\hline C.D $(P=0.05)$ & NS & NS & 9.1 & 44.60 & NS & 0.09 & 255. & 1250.1 \\
\hline \multicolumn{9}{|c|}{ Between two $\mathrm{M}$ at the same or different $\mathrm{N}$} \\
\hline $\mathrm{SEm} \pm$ & 2.93 & 4.01 & 2.9 & 14.61 & 0.00 & 0.01 & 76.4 & 417.7 \\
\hline C.D $(\mathbf{P}=\mathbf{0 . 0 5})$ & NS & NS & 9.2 & 45.14 & NS & 0.10 & 260. & 1263.7 \\
\hline
\end{tabular}

NS-Not significant 
Table.2 Days to 50 per cent flowering and days to physiological maturity of rice as influenced by organic manuring options and nitrogen levels

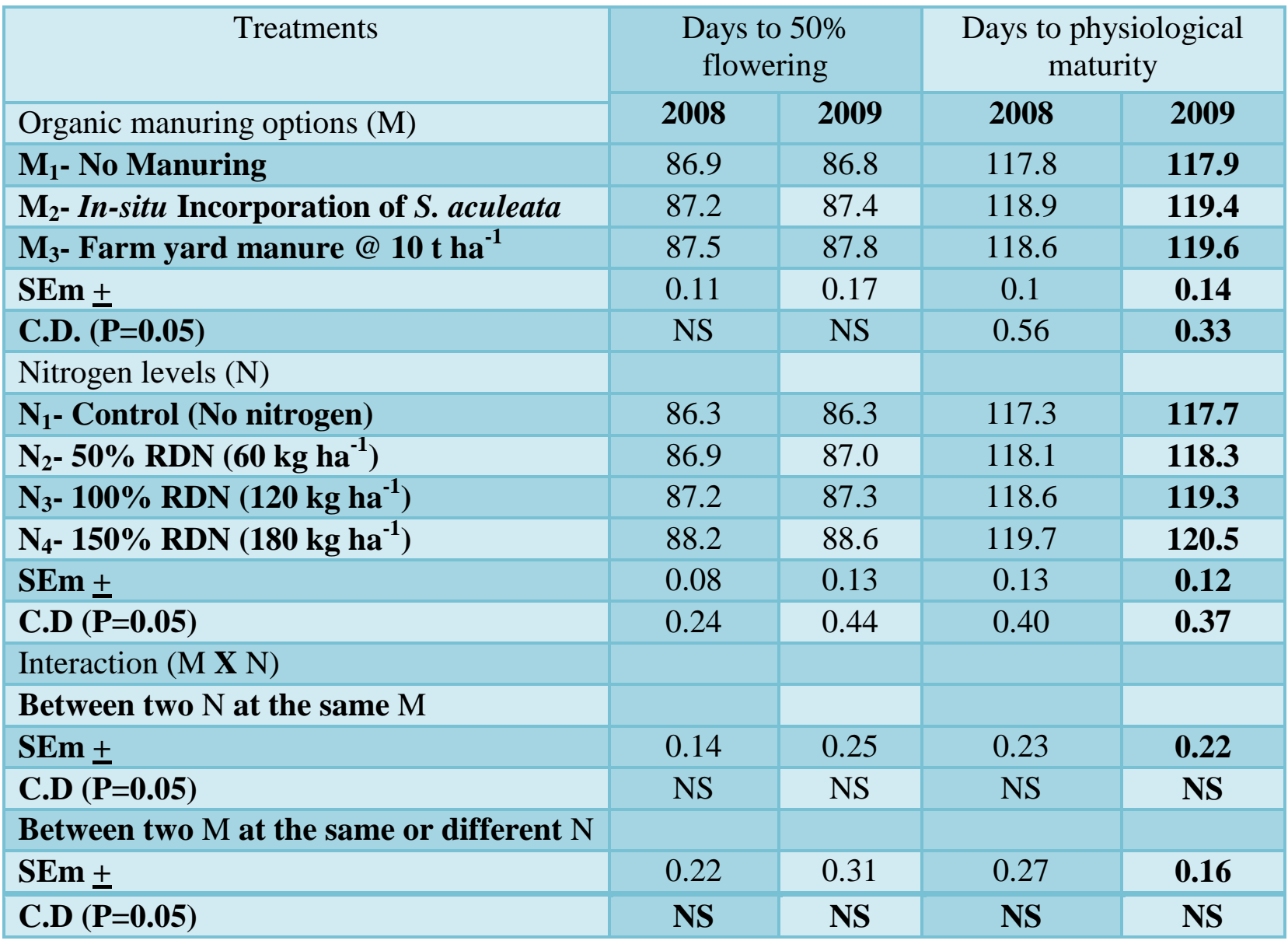

NS-Not significant

Fig.1 Leaf chlorophyll content (SPAD values) of rice crop at 50 per cent flowering as influenced by organic manuring options and nitrogen levels

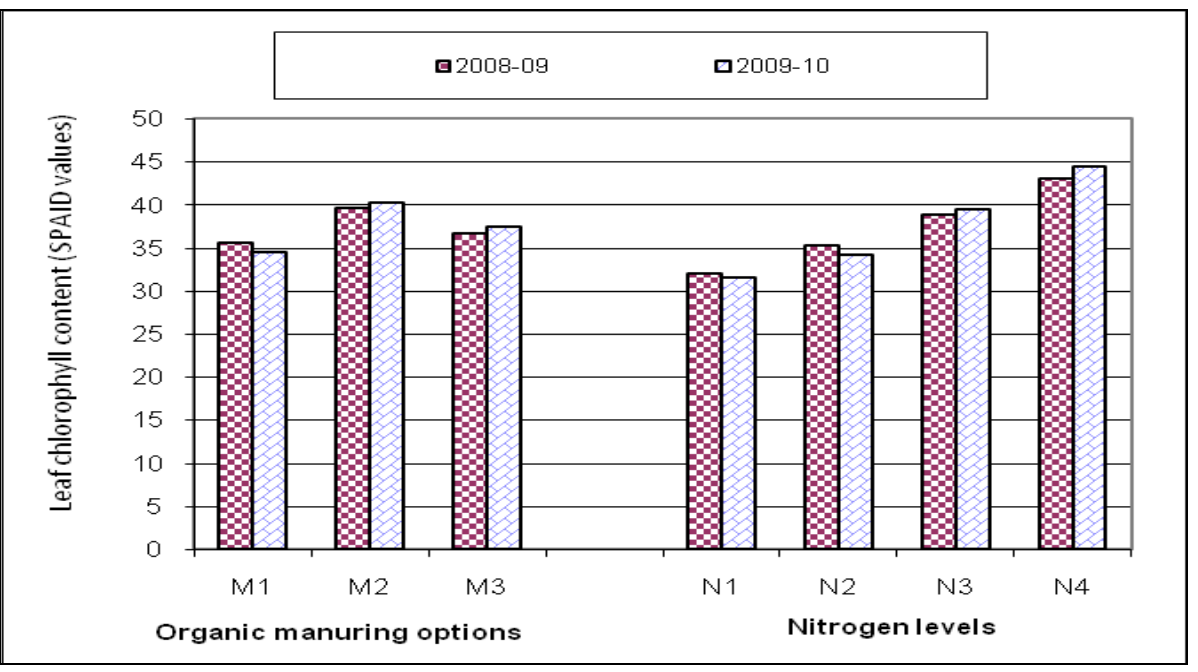


Table.3 Leaf chlorophyll content (SPAD values) and percent solar radiation intercepted by the rice crop canopies at 50 per cent flowering as influenced by organic manuring options and nitrogen levels

\begin{tabular}{|c|c|c|c|c|}
\hline \multirow[t]{2}{*}{ Treatments } & \multicolumn{2}{|c|}{$\begin{array}{l}\text { Leaf chlorophyll } \\
\text { content (SPAD) }\end{array}$} & \multicolumn{2}{|c|}{$\begin{array}{l}\text { Per cent solar radiation } \\
\text { interception }\end{array}$} \\
\hline & 2008 & 2009 & 2008 & 2009 \\
\hline \multicolumn{5}{|l|}{ Organic manuring options (M) } \\
\hline$M_{1}$ - No Manuring & 35.59 & 34.41 & 81.25 & 78.83 \\
\hline $\mathbf{M}_{2}$ - In-situ Incorporation of S. aculeata & 39.57 & 40.27 & 84.41 & 84.88 \\
\hline $\mathrm{M}_{3}$ - Farm yard manure @ $10 \mathrm{t} \mathrm{ha}^{-1}$ & 36.71 & 37.47 & 82.56 & 82.97 \\
\hline SEm \pm & 0.08 & 0.39 & 0.34 & 0.25 \\
\hline C.D. $(\bar{P}=0.05)$ & 0.32 & 1.53 & 1.32 & 0.97 \\
\hline \multicolumn{5}{|l|}{ Nitrogen levels $(\mathrm{N})$} \\
\hline $\mathrm{N}_{1}$ - Control (No nitrogen) & 32.01 & 31.52 & 78.93 & 76.35 \\
\hline $\mathbf{N}_{2^{-}} 50 \%$ RDN $\left(60 \mathrm{~kg} \mathrm{ha}^{-1}\right)$ & 35.28 & 34.15 & 80.74 & 79.41 \\
\hline $\mathrm{N}_{3}-100 \%$ RDN $\left(120 \mathrm{~kg} \mathrm{ha}^{-1}\right)$ & 38.87 & 39.41 & 84.88 & 85.09 \\
\hline $\mathrm{N}_{4}-150 \%$ RDN $\left(180 \mathrm{~kg} \mathrm{ha}^{-1}\right)$ & 43.00 & 44.45 & 86.42 & 88.06 \\
\hline $\operatorname{SEm} \pm$ & 0.30 & 0.45 & 0.35 & 0.40 \\
\hline C.D $(\overline{\mathbf{P}}=\mathbf{0 . 0 5})$ & 0.90 & 1.32 & 1.03 & 1.19 \\
\hline \multicolumn{5}{|l|}{ Interaction $(\mathrm{M} \mathrm{X} \mathrm{N})$} \\
\hline \multicolumn{5}{|l|}{ Between two $\mathrm{N}$ at the same $\mathrm{M}$} \\
\hline $\mathrm{SEm} \pm$ & 0.53 & 0.77 & 0.60 & 0.69 \\
\hline C.D $(\mathbf{P}=0.05)$ & NS & 2.29 & NS & 2.06 \\
\hline \multicolumn{5}{|l|}{ Between two $\mathrm{M}$ at the same or different $\mathrm{N}$} \\
\hline $\mathrm{SEm} \pm$ & 0.30 & 0.78 & 0.66 & 0.55 \\
\hline C.D $(\overline{\mathbf{P}}=\mathbf{0 . 0 5})$ & NS & 2.32 & NS & 2.13 \\
\hline
\end{tabular}

NS-Not significant

Fig.2 Per cent solar radiation intercepted by the rice crop canopy at 50 per cent flowering as influenced by organic manuring options and nitrogen levels

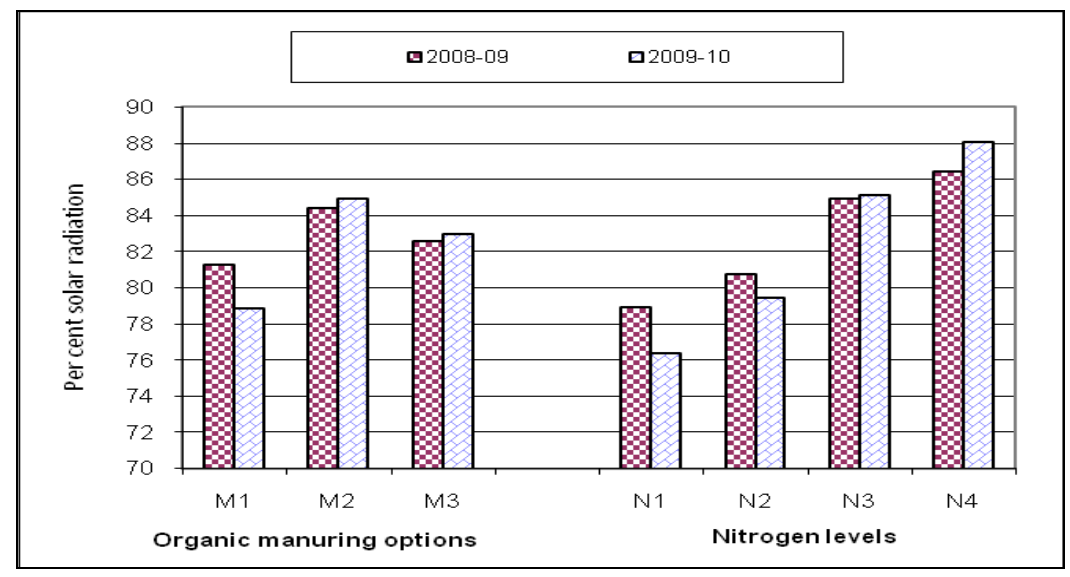


Table. 4 Number of panicles per $\mathrm{m}^{2}$ and per cent mortality of tillers in rice at maturity as influenced by organic manuring options and nitrogen levels

\begin{tabular}{|c|c|c|c|c|c|c|c|c|c|}
\hline \multirow{2}{*}{$\begin{array}{r}\text { Treatments } \\
\text { Organic manuring options (M) }\end{array}$} & \multicolumn{2}{|c|}{$\begin{array}{c}\text { Number of } \\
\text { panicles } \mathrm{m}^{-2}\end{array}$} & \multirow{2}{*}{$\begin{array}{l}\text { Mean per cent } \\
\text { mortality of } \\
\text { tillers at } \\
\text { maturity }\end{array}$} & \multicolumn{2}{|c|}{$\begin{array}{l}\text { Panicle length } \\
(\mathrm{cm})\end{array}$} & \multicolumn{2}{|c|}{$\begin{array}{l}\text { Number of } \\
\text { spikelets per } \\
\text { panicle }\end{array}$} & \multicolumn{2}{|c|}{$\begin{array}{c}\text { Filled } \\
\text { spikelets per } \\
\text { panicle }\end{array}$} \\
\hline & 2008 & 2009 & & 2008 & 2009 & 2008 & 2009 & 2008 & 2009 \\
\hline$M_{1}-$ No manuring & 216.9 & 210.4 & 26.9 & 18.0 & 18.1 & 129.8 & 122.1 & 106.7 & 99.1 \\
\hline $\mathrm{M}_{2}$ - In-situ Incorporation of S. aculeata & 313.7 & 331.4 & 20.2 & 19.5 & 20.1 & 142.3 & 147.0 & 117.3 & 120.1 \\
\hline $\mathrm{M}_{3}$-Farm yard manure @ 10 t. ha ${ }^{-1}$ & 278.8 & 355.2 & 20.3 & 18.7 & 19.7 & 139.0 & 145.3 & 114.9 & 117.9 \\
\hline $\mathrm{SEm} \pm$ & 9.97 & 8.54 & 0.82 & 0.18 & 0.07 & 2.31 & 0.73 & 1.9 & 0.5 \\
\hline C.D. $(P=0.05)$ & 39.14 & 33.53 & 3.23 & 0.66 & 0.29 & 9.07 & 2.87 & 7.6 & 2.1 \\
\hline \multicolumn{10}{|l|}{ Nitrogen levels (N) } \\
\hline $\mathbf{N}_{1}$ - Control (No nitrogen) & 195.4 & 206.1 & 28.3 & 16.9 & 17.1 & 119.7 & 114.3 & 98.0 & 92.8 \\
\hline $\mathrm{N}_{2}-50 \%$ RDN $\left(60 \mathrm{~kg} \mathrm{ha}^{-1}\right)$ & 238.4 & 261.5 & 23.9 & 17.8 & 18.3 & 132.7 & 133.3 & 110.4 & 108.5 \\
\hline $\mathrm{N}_{3^{-}} 100 \% \mathrm{RDN}\left(120 \mathrm{~kg} \mathrm{ha}^{-1}\right)$ & 299.6 & 343.4 & 19.6 & 19.6 & 20.4 & 142.6 & 145.4 & 119.2 & 119.1 \\
\hline $\mathrm{N}_{4-}-150 \%$ RDN $\left(180 \mathrm{~kg} \mathrm{ha}^{-1}\right)$ & 345.9 & 385.0 & 18.0 & 20.7 & 21.3 & 153.2 & 159.4 & 124.3 & 129.1 \\
\hline $\mathrm{SEm} \pm$ & 14.10 & 16.24 & 0.77 & 0.21 & 0.19 & 4.43 & 2.73 & 3.5 & 2.2 \\
\hline C.D $(P=0.05)$ & 41.91 & 48.24 & 2.30 & 0.62 & 0.57 & 13.15 & 8.09 & 10.6 & 6.6 \\
\hline \multicolumn{10}{|l|}{ Interaction (M X N) } \\
\hline \multicolumn{10}{|l|}{ Between two $\mathrm{N}$ at the same $\mathrm{M}$} \\
\hline $\mathrm{SEm} \pm$ & 24.43 & 28.12 & 1.34 & 0.36 & 0.33 & 7.67 & 4.72 & 6.2 & 3.8 \\
\hline C.D $(\overline{\mathbf{P}}=\mathbf{0 . 0 5})$ & NS & NS & NS & NS & NS & NS & NS & NS & NS \\
\hline \multicolumn{10}{|l|}{ Between two $M$ at the same or different $N$} \\
\hline SEm \pm & 21.15 & 20.41 & 1.58 & 0.36 & 0.21 & 5.54 & 2.68 & 4.6 & 2.1 \\
\hline C.D $(P=0.05)$ & NS & NS & NS & NS & NS & NS & NS & NS & NS \\
\hline
\end{tabular}

NS-Not significant 
Table.5 Filled spikelet's per panicle, per cent spikelet sterility, test weight (g) Grain and straw yields $\left(\mathrm{kg}^{-1} \mathrm{~h}^{-1}\right)$ and harvest index $(\%)$ of rice as influenced by organic manuring options and nitrogen levels

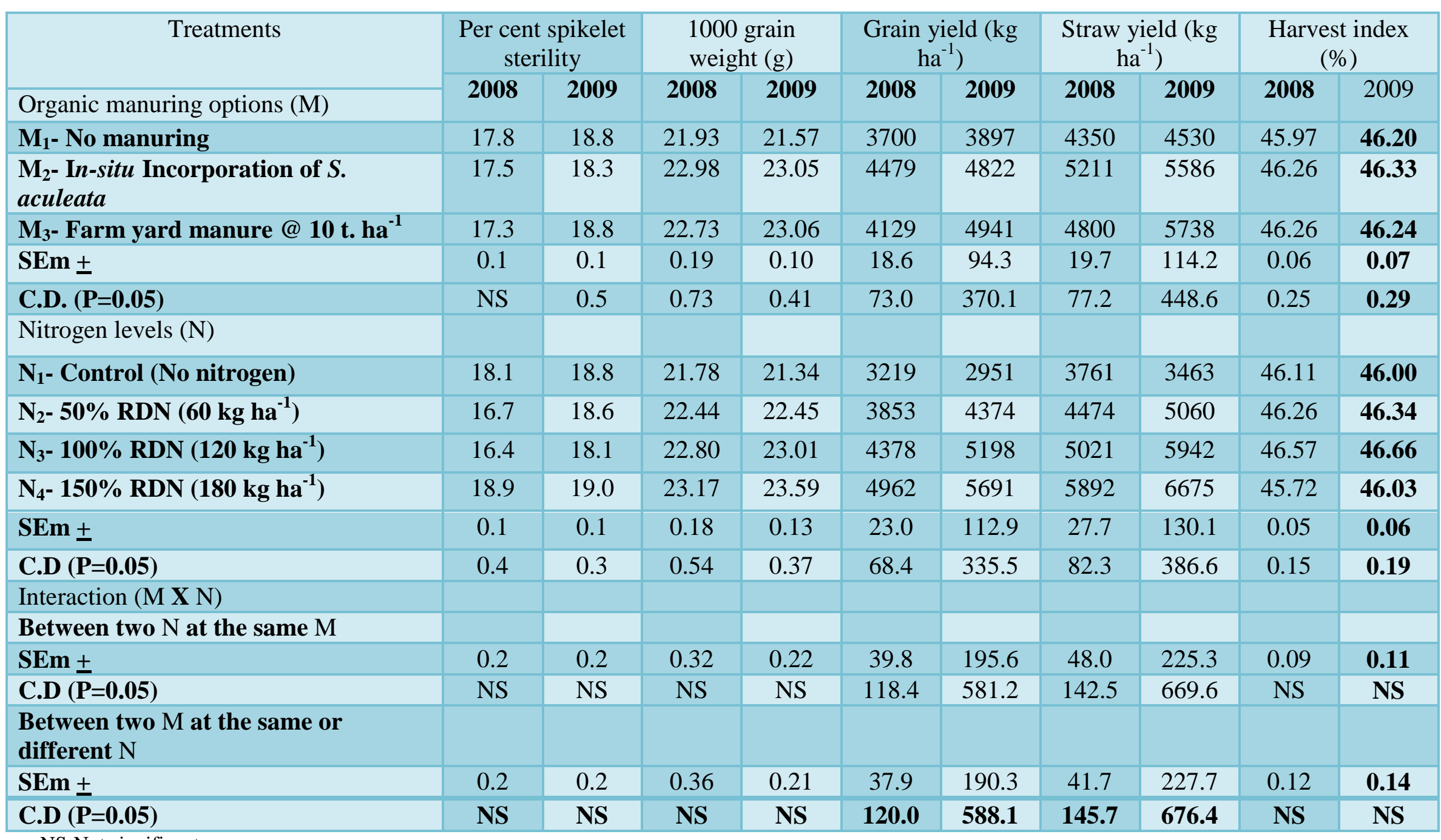

NS-Not significant 
Fig.3 Filled spikelet's per panicle, per cent spikelet sterility at maturity and test weight (g) of rice as influenced by organic manuring options and nitrogen levels

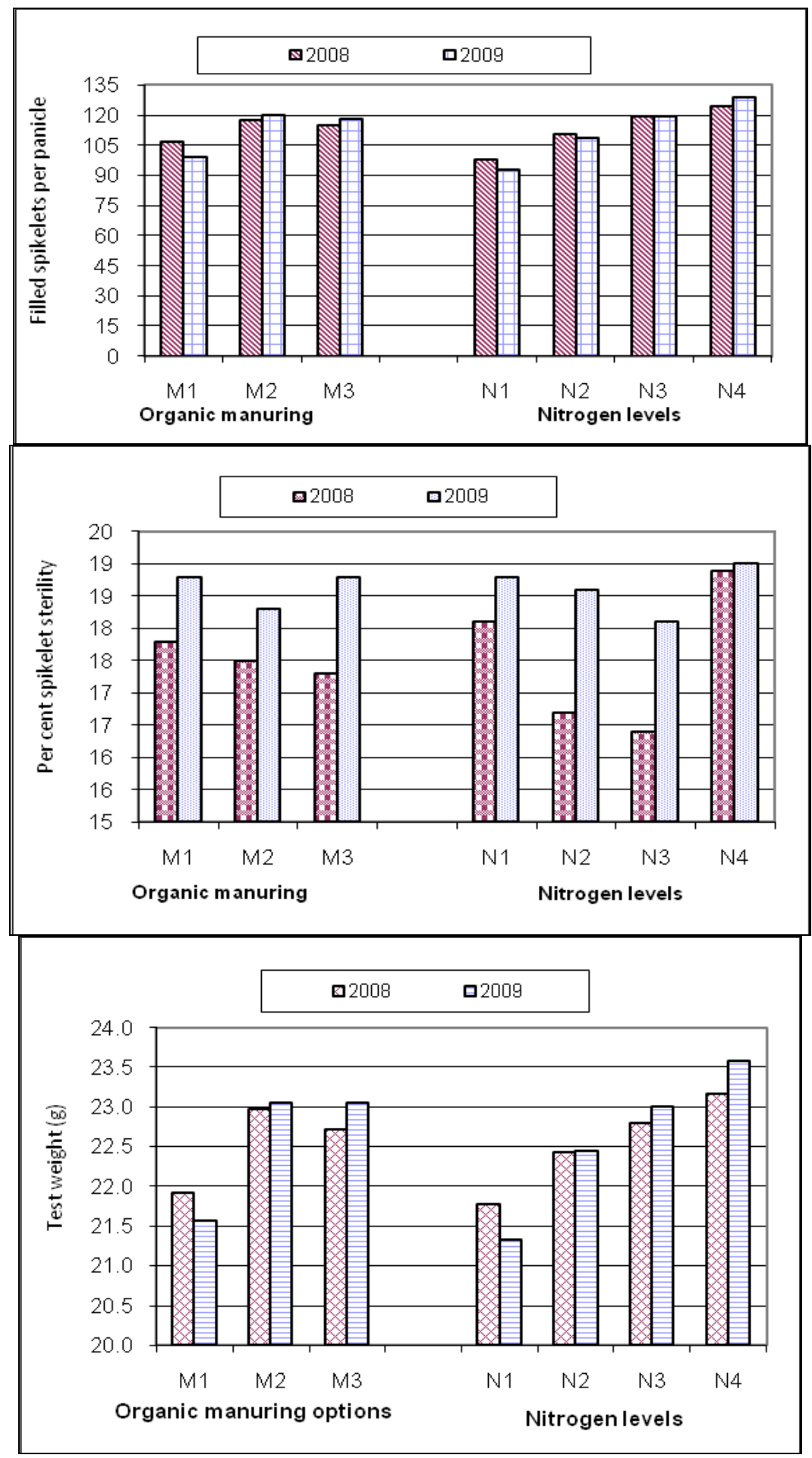


Fig.4 Grain and straw yields (kg ha-1) and harvest index (\%) of rice as influenced by organic manuring options and nitrogen levels during 2008-09 and 2009-10

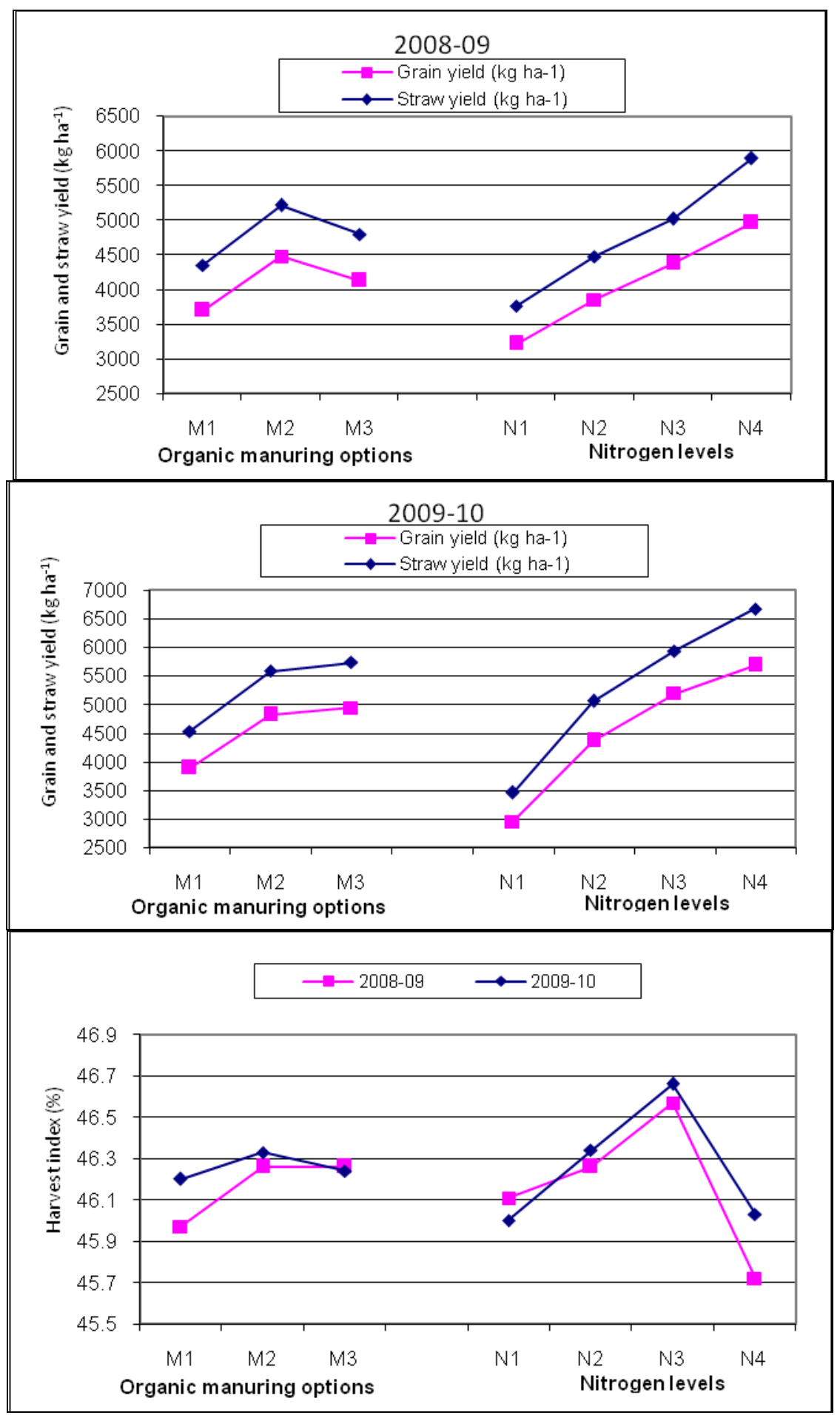


Both green manuring and FYM application to rice resulted in increased yield attributes (Table 4 and Fig 3) viz., panicle number, panicle length, number of spikelets per panicle, number of filled grains per panicle and 1000 grain weight over no manuring. However, mean per cent tiller mortality and per cent spikelet sterility were at their lowest under organic manuring in both the years. All the yield attributing characters were significantly increased due to application of nitrogen levels ranging from 0 to $150 \%$ RDN. The treatment combination of $50 \%$ of RDN + green manuring $\left(\mathrm{M}_{2} \mathrm{~N}_{2}\right)$ or $50 \% \mathrm{RDN}+\mathrm{FYM}$ @ $10 \mathrm{t} \mathrm{ha}^{-1}\left(\mathrm{M}_{3} \mathrm{~S}_{2}\right)$ resulted in numerically on par values of all the yield attributes with that of 100 and $150 \%$ RDN under no manured treatment $\left(\mathrm{M}_{1} \mathrm{~N}_{3}\right.$ and $\left.\mathrm{M}_{1} \mathrm{~N}_{4}\right)$. Adoption of green manuring / FYM resulted in a net saving of fertilizer nitrogen to an extent of $50 \%$ from that of $100 \%$ RDN. Higher harvest index values were recorded by both the organic manuring options. Whereas, nitrogen level beyond $100 \%$ RDN depressed the harvest index in both the years. The results corroborate with the findings of earlier workers with respect to panicle length (Thakur, 1993 and Gupta, 1996), number of spikelets per panicle and number of filled grains per panicle (Budhar and Palaniappan, 1997 and Muhammad Usman et al., 2003) and 1000 grain weight (Vijayapuri and Sriramachandrasekaran, 2002; Muhammad Usman et al., 2003).

Grain yield and stover yield significantly increased with organic manuring options and nitrogen levels in both the years. (Table 5 and Fig 4) Conjunctive use of green manure + $50 \%$ RDN $\left(\mathrm{M}_{2} \mathrm{~N}_{2}\right)$ and FYM @ $10 \mathrm{t} \mathrm{ha}^{-1+}$ $50 \%$ RDN $\left(\mathrm{M}_{3} \mathrm{~N}_{2}\right)$ produced statistically on par grain yields with that of $100 \%$ RDN without organic manuring $\left(\mathrm{M}_{1} \mathrm{~N}_{3}\right)$. Due to adoption of green manuring / FYM, there was a net saving of fertilizer nitrogen to an extent of $50 \%$ from that of $100 \%$ RDN. Higher harvest index values were registered due to both organic manuring options. Whereas, nitrogen level beyond 100\% RDN depressed the harvest index in both the years. Similarly, an increasing trend in grain and straw yields was noticed with increasing rate of $\mathrm{N}$ by Barik et al., 2006. Increase in harvest index due to pre-rice incorporation of organic manures might be due to steady supply of adequate nutrients meet the crop demand and favoured better partitioning of assimilates from source to sink. The results of the present study are in agreement with the findings of Radha Madhav et al., (1996).

In conclusion, the present experimental results strongly suggest that adoption of integrated nutrient management in rice is very essential from the point of productivity and sustainability. The integrated supply of green manure or FYM with chemical fertilizers in kharif rice minimized use of chemical fertilizers to a greater extent without affecting the yields and conserve the soil fertility status for succeeding crop. Application of $150 \%$ RDN increased the grain yields to an extent of $11.8 \%$ in the first year and $8.7 \%$ in the second year over $100 \%$ RDN.

\section{References}

Bajpai, R.K., Srikantchitale.,Upadhyay, S.K., and Joshi, B.S., 2004. Effect of legumecereal, cereal-legume and cereal-cereal sequences on the soil fertility status and crop productivity. Journal of Soils and Crops. 14 (1) 5-8.

BalajiNaik, B and Yakadri, M. 2004. Effect of integrated nutrient management on yield of hybrid rice (Oryza sativa L. ). Journal of Research ANGRAU. 32(2): 85-89.

Barik, A.K., Arindamdas.,Giri, A.K and Chattopadhyay, G.N. 2006. Effect of organic (vermicompost, farmyard manure) and chemical sources of plant 
nutrients on productivity and soil fertility of kharif rice (Oryza sativa L. ). Crop Research. 31(3): 339-342.

Budhar, M.N and Palaniappan, S.P. 1997. Integrated nautrient management in lowland rice. Indian Journal of Agronomy. 42(2): 269-271.

Chandrapala, A.G. 2009. Productivity of rice - maize cropping system as influenced by rice crop establishment methods and nutrient management ( $\mathrm{S}$ and $\mathrm{Zn}$ ). A Ph.D thesis submitted to Acharya N.G Ranga agril. University, Rajendranagar, Hyderabad.

Gomez, K.A and Gomez, R.A. 1984. Statistical procedures for agricultural research. II edition, John Wiley and Sons, New York. P: 680.

Gupta, S.K. 1996. Effect of planting, seeding and nitrogen on yield of rice. Indian Journal of Agronomy. 41(4): 581-583.

Kundu, D.K and Pillai, K.G. 1992. Integrated nutrient supply system in rice and rice based cropping systems. Fertilizer News. 37(4): 95-101.

Mari, N., Maitlo, N., Baber, M.A and Tunio, G.S. 2004. Green manuring in rice. Sarhad Journal of Agriculture. 20(4): 479-480.

Muhamad Usman., EhsanUllah., Ejaz Ahmed Warriach., Muhammad Farooq and Amir Liaqat. 2003. Effect of organic and inorganic manures on growth and yield of rice variety "Basmati 2000". International Journal of Agriculture and Biology. 5(4): 481-483.
Pramanik, M.Y.A., Sarkar, M.A.R., Kabir, M.H and Faruk, G.R. 2004. Effect of green manures and different levels of nitrogen on plant height, tillering behaviour, dry matter production and yield of transplanted Aman rice. Asian Journal of Plant Sciences. 3(2): 291292.

RadhaMadhav, M., Ravikumar, A and Venkateswarlu, B. 1996. Effect of different sources of nitrogen on growth, yield and nutrient uptake. The Andhra Agricultural Journal. 43(3-4): 119-122.

Roy, R.N and Braun, H. 1984. In: 'Proceedings of seminar on system approach to fertilizer industry' held in 1983 at New Delhi, FAI Part II: Abs 1 1/1: p.23.

Sunitha, A. 2003. Effect of planting pattern and integrated nutrient management on growth and yield of kharif rice. $M$. Sc. (Ag.) thesis, submitted to Acharya N. G. Rang Agricultural University, Hyderabad.

Thakur, R.B. 1993. Performance of summer rice to varying levels of nitrogen. Indian Journal of Agronomy. 38(2): 187-190.

Vajyapuri, V and Sriramachandrasekaran, M.V. 2002. Effect of green manures on growth and yield of lowland rice. Journal of Ecobiology. Faculty of Agriculture, Annamalai University, Annamalainagar 608 202, Tamil Nadu, India 14(4): 295-295.

\section{How to cite this article:}

Sudhakar, C., P. Padmavathi, B.V. Asewar, P. Venkateswar Rao and Sai Ram, A. 2018. Influence of Integrated Use of Organic Manures and Inorganic Sources of Nitrogen on Grain Yield and Its Attributes in Rice (Oryza sativa L.). Int.J.Curr.Microbiol.App.Sci. 7(11): 35263537. doi: https://doi.org/10.20546/ijcmas.2018.711.402 